\title{
CAPITAL NATIVO E REESTRUTURAÇÃO PRODUTIVA NA PRAÇA DO RECIFE: crédito hipotecário entre 1865 e 1914
}

\author{
Leonardo Milanez de Lima Leandro* \\ Renato Leite Marcondes**
}

\begin{abstract}
RESUMO: O objetivo do estudo é discutir as características do crédito hipotecário recifense frente à diminuição do ritmo de crescimento da economia pernambucana. Para tanto, foram utilizados, como fontes primárias, 5.612 contratos de hipotecas, coletados no Cartório do $1^{\circ}$ Ofício do Registro de Imóveis do Recife. Será demonstrado que o crédito foi disponibilizado majoritariamente a partir de poupanças nativas, que deram suporte à expansão da rede de serviços públicos da cidade, mantiveram o funcionamento do comércio e financiaram indústrias.
\end{abstract}

PALAVRAS-CHAVE: Capital nativo; Crédito hipotecário; Negociantes; Indústrias.

\section{Native capital and productive restructuring in Recife: mortgage credit between 1865 and 1914}

\begin{abstract}
It is proposed to discuss the characteristics of Recife mortgage credit in the face of the slowdown in the pace of growth of the economy of Pernambuco. For this purpose, 5,612 mortgages contracts were used, collected at the Office of the 1st Registry of the Real Estate of the Recife. It will be shown that the credit was mostly offered from native savings, which supported the urban expansion and the city's public services network, maintained the functioning of commerce and financed industries.
\end{abstract}

KEYWORDS: Native capital; Mortgage credit; Business men; Industries.

\section{Capital nativo e reestructuración productiva en la plaza comercial del Recife: credito hipotecario entre 1865 e 1914}

RESUMEN: O objectivo del etudio es discutir las caracteristicas del credito hipotecario en la plaza commercial de Recife, mientras el ritmo de crescimiento de la economia estava disminuindo. Foram utilizados los dados de 5,612 hipotecas, colectadas en la $1^{\text {a }}$ Oficina de Registro de Inmuebles de Recife. Será demonstrado que la major fonte de credito adveio de poupanças nativas, dando suporte a la expansión de la red de servicios urbanos y de la industria, y bien assy a las pequenas casas comerciales.

PALABRAS-CLAVE: Capital native; Credito hipotecario; Negociantes; Industrias.

\footnotetext{
* Doutor em Desenvolvimento Sócio Ambiental pelo Núcleo de Altos Estudos Amazônicos da Universidade Federal do Pará (UFPA). Atualmente é pesquisador do Programa de Pós-Graduação em Economia da Faculdade de Economia, Administração e Contabilidade de Ribeirão Preto, Universidade de São Paulo (FEA-RP/USP), e Bolsista do Programa Nacional de Pós-Doutorado da Coordenação de Aperfeiçoamento de Pessoal de Nível Superior (CAPES). Contato: Avenida Bandeirantes, 3900, Monte Alegre, CEP: 14040-905, Ribeirão Preto - SP, Brasil. E-mail: leo.milanez@gmail.com.

** Doutor em História Econômica pela Universidade de São Paulo. Atualmente é professor do departamento de economia da Faculdade de Economia, Administração e Contabilidade de Ribeirão Preto, Universidade de Sâo Paulo (FEA-RP/USP). Contato: Avenida Bandeirantes, 3900, Monte Alegre, CEP: 14040-905, Ribeirão Preto, SP, Brasil. E-mail: rlmarcon@usp.br.
} 


\section{Introdução}

A economia pernambucana enfrentou ciclos que, ao final, lenta e continuadamente, diminuíram seu ritmo de crescimento (EISENBERG, 1977; LEVINE, 1980; VERGOLINO, 1993; GALVÃO, O., 2015). Ingressou no século XIX ainda gozando de bom momento econômico e o seu porto, a cidade do Recife, por onde escoava a produção de outros estados nordestinos, era o segundo mais importante do país (ALBUQUERQUE, 2014; LEVINE, 1980; DE CARLI, 1938). Em meados do século XIX, quando o açúcar brasileiro havia perdido seus principais mercados, o mesmo acontecendo com o algodão ${ }^{1}$, a cidade passou a experimentar e aprofundar processos de crescente urbanização.

Embora a lavoura fosse um representante de importância capital para a formação da riqueza pernambucana, a economia recifense iniciou uma trajetória de modernização, tornando-se cada vez mais urbana e industrial (SINGER, 1977; DOMINGUES, 2000). Enquanto as exportações de produtos da lavoura representaram a sua principal função econômica, a intensidade do fluxo comercial oferecia condições para a acumulação de capital, formando poupanças com capacidade para induzir o dinamismo econômico da cidade. Assim, a economia do Recife se manteve aquecida, e mesmo com a diminuição do ritmo de crescimento da economia pernambucana, teve condições de se modernizar e adaptar suas estruturas de serviços comerciais e financeiros para atender a uma demanda interna de consumo crescente (SINGER, 1977). A partir da segunda metade do século XIX, diversos estímulos ao mercado de capitais ${ }^{2}$ buscaram melhorar as condições de financiamento aos empreendimentos econômicos. Nesse contexto de reestruturação produtiva, uma parte do capital acumulado passou a ser negociado por meio de hipotecas.

Pesquisas têm demonstrado a relevância dessas fontes para o suporte e fundamentação empírica de interpretações historiográficas focadas na questão do crédito ${ }^{3}$. Desse modo, com base na análise de 5.612 contratos de hipotecas, localizados no Cartório do $1^{\circ}$ Ofício do Registro de Imóveis do Recife ${ }^{4}$, serão discutidas as características do crédito hipotecário na praça recifense, na intenção de verificar o movimento geral do mercado, o perfil de seus agentes e as principais atividades que demandaram aquele crédito.

A discussão será conduzida ao longo de outras três sessões, além desta introdução e das considerações finais. A seguir, o panorama da formação econômico-social do Recife sugere que sua estrutura produtiva estava se reorientando para o atendimento das demandas internas, bem como oferece uma noção preliminar dos grupos de credores e devedores. $\mathrm{Na}$ sequência, é procedida uma caracterização da praça hipotecária recifense com base nos documentos coletados nos livros de registros hipotecários. As atuações de negociantes, 
bancos, capitalistas e o lançamento de debêntures, são analisadas na penúltima sessão, na intenção de melhorar o entendimento da dinâmica daquela praça. Por fim, são feitos apontamentos e considerações finais. Como fontes, além dos registros hipotecários, foram utilizados os Censos, Almanaques de Pernambuco, Relatórios de Governo, jornais da época e outros dados disponíveis nas bases do IPEA e do IBGE.

\section{Recife no século XIX}

A formação e desenvolvimento do Recife têm raízes na importância assumida pelo seu porto (ANDRADE, 1973), que conectava a cidade com os principais centros do capitalismo mundial (MELO, 1976). Embora tenha tirado proveito das exportações de algodão, sua principal função econômica se concentrava nas exportações de açúcar: o Recife era uma “cidade do açúcar” (FERLINE, 1994). Ao longo do século XIX, assim como outros centros metropolitanos mundiais, experimentou a modernização da paisagem e dos serviços urbanos, consolidando transformações ao final daquele século (GALVÃO, S., 1899; MELLO, 1930; JUCÁ, 1975; SINGER, 1977). Diversificando suas funções no último quarto do século XIX, ampliou sua importância urbana (SINGER, 1977) e assistiu a consolidação de um setor industrial após a virada republicana (MELLO, 1930).

Como polo de desenvolvimento regional, para onde eram canalizadas as produções de províncias circunvizinhas, a indução das transformações na cadeia produtiva da economia pernambucana estava atrelada ao desempenho do setor de mercado externo (VERGOLINO, 1993). Conforme anotou Singer (1977), o crescimento do setor de mercado interno era dependente daqueles resultados. Assim, a observação do comportamento de variáveis que estão com esses setores relacionados, pode oferecer uma noção da evolução socioeconômica da praça recifense ${ }^{5}$.

\section{Comércio exterior e demografia}

Após o conflito civil nos Estados Unidos, o açúcar brasileiro, que havia cedido espaço ao algodão na cesta de exportações, retomou sua posição. O parque açucareiro, com a política dos engenhos centrais ${ }^{6}$, recebeu importantes inovações, dotando-o de maior capacidade de produção (SINGER, 1977; EISENBERG, 1977). Mas a busca pela modernização implicava, necessariamente, na importação de máquinas e equipamentos. De outro lado, o preço competitivo dos sucedâneos havia atraído tanto os mercados tradicionais quanto os novos mercados (EISENBERG, 1977). A partir dali, os preços alcançados pelo açúcar no mercado 
mundial não foram substantivos para manter o padrão de acumulação e de crescimento econômico como dantes. Esses fatores podem explicar a elevação do valor das importações após a segunda metade da década de 1870, enquanto o baixo preço do açúcar implicou na retração do valor das exportações, fazendo sua contribuição à economia local praticamente estagnar até o final do império (EISENBERG, 1977; VERGOLINO, 1993).

Nas primeiras décadas do século XX, mesmo com os bons resultados apresentados no período da Primeira Guerra, as exportações pelo Recife continuaram em queda, sem conseguir superar as importações. Note-se, nesse ínterim, que o açúcar de Pernambuco passou a abastecer o mercado interno, mantendo as importações com os saldos superavitários do comércio interior.

Outra perspectiva da perda de dinamismo no setor de mercado externo pode ser obtida pela comparação dos dados do comércio exterior com a evolução demográfica da cidade. A população recifense em $1872^{7}$ era de 92 mil habitantes, chegando a 113 mil em 1900. A taxa geométrica de crescimento anual da população de $0,7 \%$ no intervalo confirma um ritmo de crescimento populacional lento. A expansão mais intensa ocorreu entre 1900 e 1920, quando a população chegou a quase 242 mil habitantes e aquela taxa foi de $3,9 \%$ ao ano. Por outro lado, a movimentação do comércio exterior per capita foi reduzida a quase metade de 1872 até 1910, retornando ao patamar da década de 1870 só nos últimos anos da Primeira Guerra. Vale enfatizar que o dinamismo é devido especialmente ao peso das importações.

Andrade (1973) pontuou que a verificação da evolução do número de equipamentos comerciais aplicados no ramo das importações e exportações oferece uma medida de avaliação do nível do dinamismo do setor de mercado externo. Ao observar os Almanaques de Pernambuco entre os anos de $1864^{8}$ e $1894^{9}$, as listas dos chamados negociantes de grosso trato que atuavam na praça do Recife foram progressivamente diminuindo, de modo que em 1894 havia pouco mais da metade daqueles que atuavam em 1864. De outro lado, o número de estabelecimentos dedicados ao pequeno comércio havia praticamente dobrado naquele interstício.

Mesmo que as contagens censitárias e anotações feitas nos relatórios oficiais e nos almanaques apresentem falhas e equívocos, ou que haja problemas de qualquer natureza que desabonem a precisão dos dados, é razoável inferir que a cidade do Recife, do ponto de vista demográfico, cresceu, enquanto a diminuição da renda per capita gerada pelas atividades econômicas regionais foi implicada pela perda de dinamismo do setor de mercado externo, basicamente dependente dos produtos da lavoura, cuja capacidade de formação de riqueza havia perdido o intenso vigor apresentado nos séculos anteriores. Ademais, o crescimento 
demográfico faz emergir uma demanda por moradia, que por sua vez cria condições para a expansão imobiliária da cidade. E a expansão e a diversificação do setor de mercado interno deram suporte ao atendimento das demandas de consumo local.

\section{Indústria e finanças}

A respeito da diversificação das funções econômicas da cidade do Recife, cumpre pontuar que para além de oferecer equipamentos comerciais de toda sorte, dedicados ao abastecimento da praça, os parcos resultados oferecidos pelas exportações da lavoura pernambucana findou por criar condições para a emergência de um parque fabril para processar a matéria prima ali originada. No plano geral, há uma tendência de crescimento do número de estabelecimentos fabris sediados no Recife, com notável emergência da indústria do algodão. Entre os anos de 1864 e 1894, as unidades fabris existentes saltaram de $103^{10}$ para $205^{11}$. Cabe lembrar ainda que o número de engenhos relacionados nas freguesias da cidade diminuiu, sugerindo um avanço da rede urbana sobre os espaços outrora rurais ${ }^{12}$.

Para a primeira década do século XX, vale recorrer aos dados do Censo Industrial de 1907. O levantamento registrou 55 fábricas onde trabalhavam 5.474 operários, com capital total aplicado de 29 mil contos de réis. Os dados reforçam a ideia da reestruturação econômica que vinha ocorrendo no Recife, não mais completamente dependente dos produtos de exportação, mas com um departamento industrial em crescimento ${ }^{13}$.

Nota-se, assim, as condições favoráveis à ampliação e fortalecimento do pequeno comércio, que abastecia a população, uma vez que havia um contingente razoável e crescente de pessoas que não dispunham de condições de produzir seus meios de subsistência, ou melhor, um contingente cuja subsistência dependia da aquisição de bens de consumo por elas não produzidos. Com um departamento industrial em crescimento ${ }^{14}$, a economia da cidade vinha se livrando da dependência do setor de mercado externo, reorientando sua atividade para o atendimento das demandas de consumo interno.

Em que pese a economia pernambucana, basicamente dependente do setor de mercado externo, ter diminuído seu ritmo de crescimento, a praça do Recife apresentava certo dinamismo, com o departamento industrial em expansão, assim como das unidades que colocavam à disposição da população gêneros para a satisfação de praticamente todas as necessidades de consumo. Por outro lado, a forte vinculação com os produtos dominantes da economia pernambucana, tradicionalmente voltada à exportação, implicou em situações 
críticas, nas quais movimentos de avanço e retração da atividade econômica concorrem para a abertura ou fechamento de firmas.

Por fim, cumpre pontuar a evolução do setor financeiro da economia recifense. Como importante porto de exportação, era de se esperar que o setor tivesse certo grau de desenvolvimento, com casas filiais dos principais bancos que atuavam no Brasil, tanto de capital nacional quanto internacional. Além dessas, outras instituições locais reuniram capitais para dar suporte aos negócios em expansão na praça da capital pernambucana. Havia ainda as firmas estrangeiras e nacionais, que faziam o papel de agências de bancos, nacionais e estrangeiros, e proporcionavam a circulação do capital na praça do Recife ${ }^{15}$.

De meados do século XIX até a reforma hipotecária da década de 1860, havia o Banco de Pernambuco e a Caixa Econômica e Monte de Socorro do Recife, a caixa filial do Banco do Brasil ${ }^{16}$, a casa bancária Mauá \& Cia., caixas filiais do London and Brazilian Bank ${ }^{17}$ e do English Bank of Rio de Janeiro ${ }^{18}$, além das agências de negociantes locais e internacionais aplicados no comércio de importação e exportação, que operavam câmbio e faziam descontos de letras da praça e saques na Inglaterra, França, Alemanha, Portugal, Bélgica, Espanha. Como representantes destas, as casas de Antonio Luiz de Oliveira Azevedo \& Cia., que intermediava as operações do banco português União do Porto ${ }^{19}$, e a casa de A. Schaffter \& Cia., que operava em nome do suíço Saint Gall ${ }^{20}$.

O setor pouco avançou nas décadas posteriores. Na década de 1870, alguns bancos internacionais ainda operavam por intermédio de agenciadores. A casa de Borstelmann \& Cia. servia como agência do Deutsch Brazilianische Bank, com sede em Hamburgo. Os portugueses Banco do Minho e Banco Commercial de Braga atuavam por intermédio da casa Joaquim José Gonçalves Beltrão \& Filho e através do abastado capitalista Jorge Tasso ${ }^{21}$, respectivamente. Vale lembrar, ainda, as casas de Augusto Frederico de Oliveira, Amorim Irmãos, Baltar \& Oliveira ${ }^{22}$.

No último quarto do século XIX, algumas iniciativas para a fundação de bancos conforme a Lei das Hipotecas não lograram êxito ${ }^{23}$. Apenas em 1885 é que foi criado o Banco de Crédito Real de Pernambuco ${ }^{24}$, com o objetivo de fazer empréstimos sob garantia de hipotecas na forma da legislação hipotecária. Vale ressaltar que este não era um banco comercial e veio a se tornar o principal credor hipotecário da praça recifense. Em meio à política do Encilhamento, dois bancos emissores foram criados com sede no Recife. Um deles, o Banco Sul-Americano de Pernambuco ${ }^{25}$, não demorou muito a encerrar suas operações. O outro, com papel relevante, foi o Banco Emissor de Pernambuco ${ }^{26}$, habilitado a operar carteiras de emissão, comercial e hipotecária. Outros bancos ${ }^{27}$, como o Banco Popular 
de Pernambuco, instalado em $1891^{28}$, e o Banco do Recife, formado em $1900^{29}$, integravam a fração nacional do capital bancário aplicado no Recife. Outros bancos estrangeiros atuantes no Recife ${ }^{30}$ eram a Caixa de Crédito Industrial, de Portugal, o Parrs Banking Company Limited e o London and River Plate Bank Limited ${ }^{31}$, estes da Inglaterra.

Ao serem enumerados alguns atributos representativos das dinâmicas que imprimiram as marcas da formação econômico-social do Recife na segunda metade do século XIX e início do século XX, buscou-se oferecer uma perspectiva do ambiente de transações do mercado hipotecário. Pelo panorama, pode-se perceber uma configuração preliminar dos grupos de credores e devedores, e dos setores capazes de ofertar e demandar crédito na praça da capital pernambucana.

\section{Crédito hipotecário na praça do Recife}

Traçadas aquelas linhas gerais, é momento de avançar sobre as características específicas do mercado. Com os microdados dos contratos hipotecários é possível verificar o número de operações e o volume de recursos negociados por ano, as condições praticadas nos contratos, o perfil de seus agentes, tipo e localização das garantias oferecidas. Com esses apontamentos, ter-se-á condições de analisar o comportamento geral do mercado ao longo do tempo, bem como delimitar a participação relativa de cada grupo de agente.

Ao que parece, os marcos institucionais que delimitaram o desenvolvimento do mercado de crédito no Brasil não proporcionaram dinamismo ao mercado hipotecário da capital pernambucana, apesar da tendência inicial de expansão dos negócios ${ }^{32}$ (Gráfico 1).

Os ciclos do mercado apresentam dois momentos de razoável ampliação da oferta de crédito. O primeiro ocorreu até primeira metade da década de 1870, quando crescem o número de operações e o volume de recursos negociados ${ }^{33}$. Desde 1875 , o mercado se retraiu progressivamente pelos 10 anos seguintes. As importações necessárias para a modernização do parque açucareiro não foram acompanhadas de uma ampliação, mas por uma retração, da oferta de crédito na praça recifense. Nos anos finais do Império, o volume de recursos negociados sofreu um pequeno incremento, mantendo-se num patamar relativamente estável após a virada republicana.

Curioso é notar que mesmo com a criação do banco Emissor de Pernambuco, que entre os anos de 1890 e 1892 lançou mais de 20 mil contos de réis em moeda, além de pouco mais de 7,7 mil contos em títulos do governo (METTENHEIM, 2016), não ocorreram alterações significativas no mercado ${ }^{34}$. O aumento do meio circulante provocado pelas 
emissões daquele banco no período não se traduziram em créditos hipotecários, ainda que a instituição estivesse autorizada a operar tal carteira ${ }^{35}$. Tanto o volume de recursos quanto o número de operações não foram significativamente expandidos, e mantiveram-se relativamente estáveis até o início do século XX. Naquele momento, a situação menos favorável aos negócios foi agravada pela política fiscal de Murtinho. O mercado então encolheu novamente, ensaiando uma recuperação no prelúdio da Primeira Guerra Mundial.

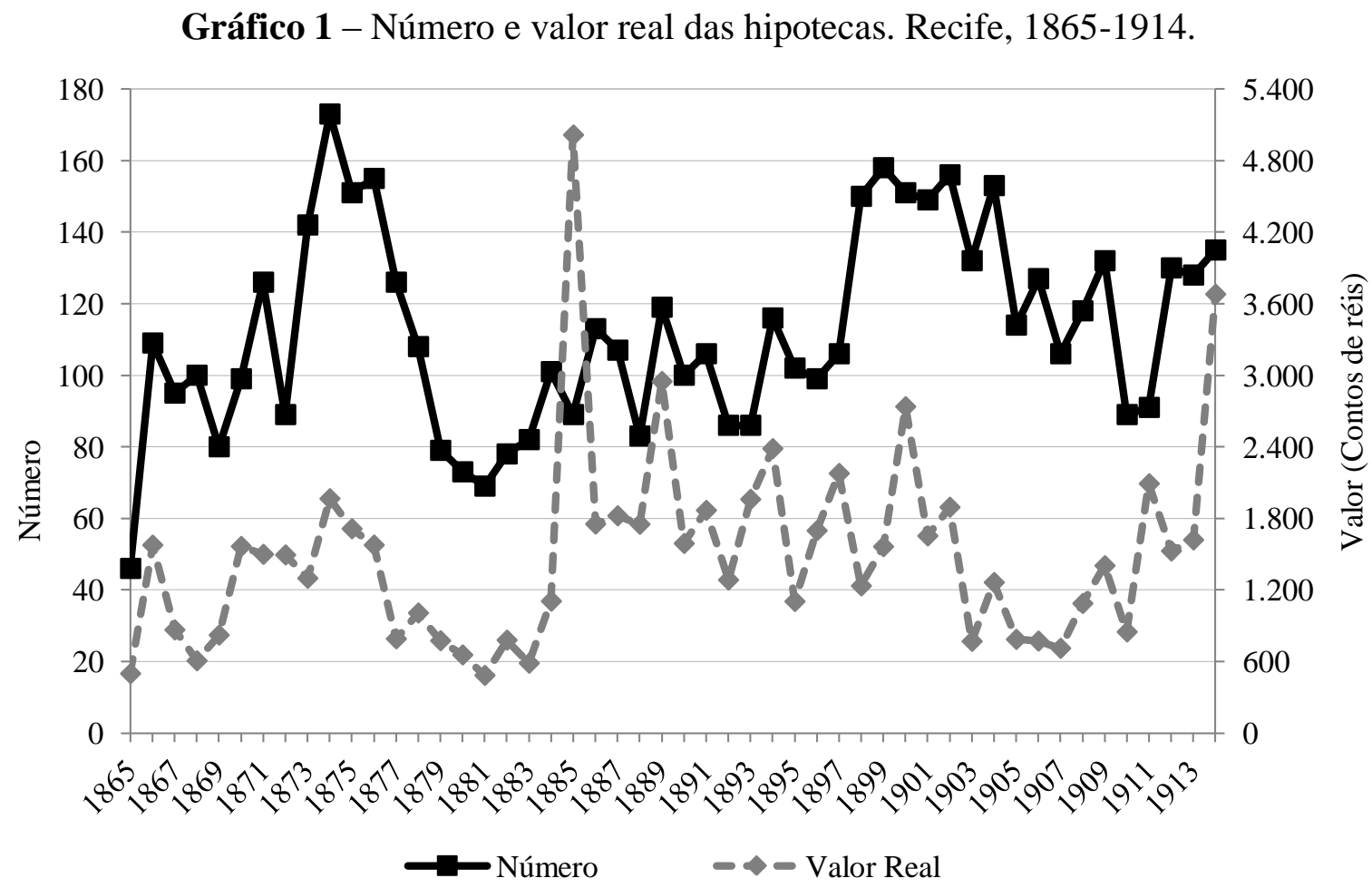

Fonte: Livros de Registros de Hipotecas, Cartório do $1^{\circ}$ Ofício de Registros de Imóveis do Recife.

Depois desse quadro mais geral, as séries de dados de prazos e juros registrados nas hipotecas sugerem as condições sob as quais eram negociados os empréstimos (Gráfico 2). Tais condições sofreram bruscas variações ao longo do tempo, mas estão marcadas 3 linhas de tendências. No período 1865-1885, o prazo médio praticado pelos agentes esteve próximo de 1,5 ano e foi ampliado a 5 anos entre 1885 e 1894. Logo em seguida, nos anos finais do século XIX, foram bruscamente encurtados, demonstrando uma possibilidade de novo alargamento até os anos que antecederam à Primeira Guerra. 
Gráfico 2 - Prazo médio e taxa de juros das hipotecas. Recife, 1865-1914.

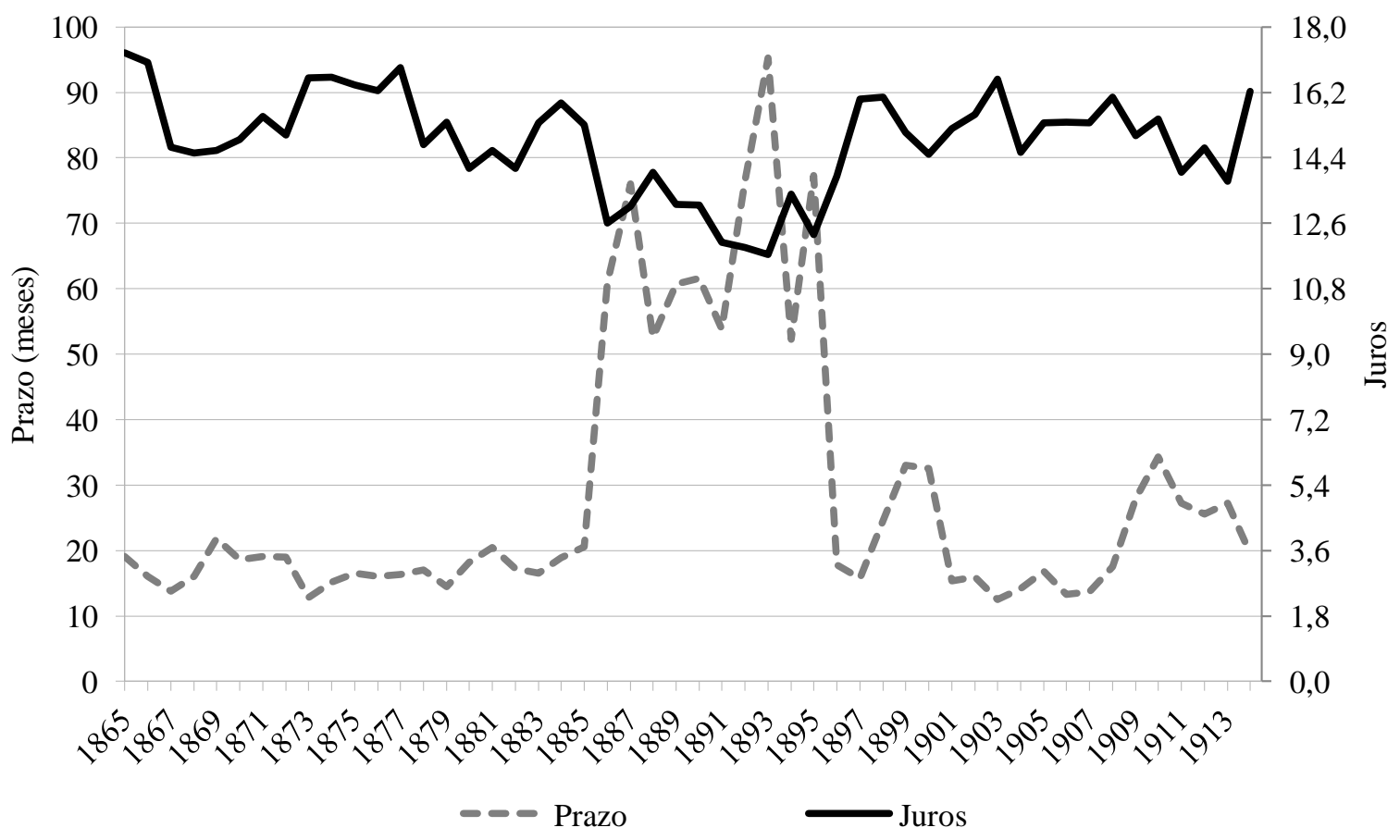

Fonte: Livros de Registros de Hipotecas, Cartório do $1^{\circ}$ Ofício de Registros de Imóveis do Recife.

Apesar da oscilação pronunciada da série de juros, é possível observar uma tendência de rebaixamento das taxas praticadas até 1893. Saíram do patamar médio de $15,6 \%$ no período 1865-1869 para a marca de 14,8\% anuais no período 1880-1884. Tenderam a um rebaixamento ainda mais intenso do final do império até se passarem os anos turbulentos do Encilhamento, caindo a 13,6\% no quinquênio 1885-1889 e 12,5\% no intervalo 1890-1894, marcando 11,7\% em 1893. Uma nova elevação nos anos finais do século XIX pôs juros a oscilarem em torno do patamar dos $15,4 \%$ até o final da primeira década do século XX, quando uma nova tendência de queda trouxe os juros à casa dos $14,8 \%$ anuais antes da Primeira Guerra.

Um fator explicativo para a flutuação das condições praticadas, tanto a queda dos juros quanto a alargamento dos prazos, está no ingresso dos bancos no mercado. Esses agentes cobravam taxas nominais ao redor dos $9 \%$ ao ano em contratos com prazos em torno dos 8 anos, na média. Contribuíram, dessa forma, para rebaixar os juros e alargar os prazos. De outro lado, a política restritiva de Murtinho na virada do século praticamente expulsou os bancos do mercado hipotecário, fazendo as condições piorarem de modo pronunciado.

Para melhorar o entendimento da dinâmica das operações e obter uma noção mais apurada de quem ofertava e de quem demandava crédito no mercado hipotecário, inferindo 
sobre a origem do capital e o destino das aplicações, é necessário observar outros dados das hipotecas. As garantias oferecidas nos contratos sustentam as inferências a respeito dos destinos das aplicações, e participação de credores e devedores será analisada com base no seu perfil (moradia e ocupação). A localização da moradia ainda servirá de base para a interpretação da origem do capital.

Com relação às garantias dos empréstimos, os imóveis situados no Recife foram responsáveis por lastrear quase que a totalidade dos valores contratados. Os imóveis residenciais suportaram 66,7\% dos valores negociados, e os bens de propriedades industriais representaram um valor importante, em torno de 18,6\% do total, aí incluídos os valores garantidos com engenhos. Entre estes, havia 4 contratos que arrolaram 93 escravos, em seu conjunto $^{36}$. Os bens de propriedades de empresas de serviços públicos e os prédios comerciais garantiram $12,7 \%$ dos valores. Outras garantias envolveram terrenos e bens diversos, como embarcações, empresas e animais, aceitos em $2 \%$ de todo montante.

Na Tabela 1 estão expressos os valores representativos da localização das moradias de credores e devedores, tanto do ponto de vista do número de contratos realizados quanto dos valores negociados.

Tabela 1 - Moradia de credores e devedores do mercado hipotecário. Recife, 1865-1914.

\begin{tabular}{lrrrr}
\hline \multicolumn{1}{c}{ LOCAL $^{\mathrm{a}}$} & \multicolumn{2}{c}{ CREDOR } & \multicolumn{2}{c}{ DEVEDOR } \\
& $\%$ N. & \multicolumn{1}{c}{$\%$ \$ } & $\%$ N. & \multicolumn{1}{c}{$\%$ \$ } \\
\hline Capital & 94,6 & 84,6 & 94,5 & 84,1 \\
Interior de Pernambuco & 2,9 & 3,4 & 4,5 & 5,4 \\
Resto do Brasil & 0,7 & 8,0 & 0,6 & 7,7 \\
Exterior & 1,8 & 4,0 & 0,4 & 2,8 \\
\hline
\end{tabular}

${ }^{\text {a }}$ Não havia indicação do domicílio dos credores em 45 casos e de devedores em 55 , que correspondem a $0,5 \%$ dos valores emprestados e captados.

Fonte: Livros de registros hipotecários, Cartório do $1^{\circ}$ Registro de Imóveis do Recife.

Os resultados demonstram que mais de 9/10 dos agentes residiam no Recife e mais de 4/5 dos valores foram emprestados ou tomados por agentes domiciliados na capital pernambucana, evidenciando, assim, que se tratava de um mercado fundamentalmente local, não havendo grande expressão de agentes ou capitais oriundos de fora da cidade, ou mesmo do estado de Pernambuco.

$\mathrm{Na}$ tentativa de sedimentar o perfil dos agentes e obter uma noção mais apurada sobre quem ofertava e demandava crédito na praça do Recife, cumpre analisar as ocupações 
declaradas no ato de registro do contrato hipotecário, relacionando-as com o número de contratos e o montante negociado por cada categoria (Tabela 2).

Tabela 2 - Participação de credores e devedores, por categoria, no mercado hipotecário. Recife, 1865-1914.

\begin{tabular}{lrrrr}
\hline \multirow{2}{*}{ Ocupação do Agente } & \multicolumn{2}{c}{ Credor $^{1}$} & \multicolumn{2}{c}{ Devedor $^{2}$} \\
\cline { 2 - 5 } & \multicolumn{1}{c}{ N. $^{\mathbf{0}}$} & \$Real & \multicolumn{1}{c}{${ }^{\text {o }}$} & \$ Real \\
\hline Negociantes & 1.644 & $19.870,2$ & 1.052 & $25.201,1$ \\
Bancos & 408 & $11.947,1$ & 1 & 98,4 \\
Debenturistas & 19 & $9.789,0$ & 0 & 0 \\
Capitalistas & 963 & $7.281,0$ & 17 & $1.083,6$ \\
Setor público & 294 & $5.382,0$ & 1 & 0,7 \\
Proprietários & 406 & $3.123,4$ & 1.525 & $11.594,1$ \\
Companhias & 11 & $1.337,4$ & 7 & $4.393,2$ \\
Lavradores & 38 & $1.203,0$ & 158 & $3.358,4$ \\
Funcionários públicos & 94 & 648,2 & 81 & 784,0 \\
Serviços & 67 & 615,6 & 38 & 315,7 \\
Serviços públicos & 11 & 276,0 & 9 & $5.678,6$ \\
Industriais & 4 & 85,8 & 43 & $4.087,2$ \\
Outros & 184 & $4.122,0$ & 263 & $2.149,2$ \\
Total & $\mathbf{4 . 1 4 3}$ & $\mathbf{6 5 . 6 8 0 , 7}$ & $\mathbf{3 . 1 9 5}$ & $\mathbf{5 8 . 7 4 4 , 2}$ \\
\hline
\end{tabular}

${ }^{1}$ Há 1.469 registros, correspondentes a 8.930,3 contos de réis, nos quais não foram declaradas as ocupações dos credores.

${ }^{2}$ Há 2.417 registros, correspondentes a 15.866,8 contos de réis, nos quais não foram declaradas as ocupações dos devedores.

Fonte: Livros de registros hipotecários, Cartório do $1^{\text {o }}$ Registro de Imóveis do Recife.

Os negociantes se destacaram como a principal fonte de recursos, seguidos pelos bancos. O lançamento de debêntures, apesar de não ser um recurso usual, colocou-se como a terceira maior fonte de captação de recursos. Os capitalistas também ofertaram um valor importante. As instituições públicas, os proprietários, as grandes companhias e os lavradores completam o conjunto dos maiores credores. Outros agentes aplicados em diversos ramos de atividades, como funcionários públicos, prestadores de serviços, profissionais liberais, advogados, artistas, cooperativas, clubes, hospitais, empresas de serviços públicos, industriais, militares também se envolveram nos negócios hipotecários.

Os negociantes também se mostraram os mais importantes tomadores. Proprietários, empresas de serviços públicos, companhias e industriais seguem na fila dos principais demandantes do crédito hipotecário. Os recursos captados pela lavoura foram inferiores àqueles emprestados aos industriais. Por fim, capitalistas e funcionários públicos tomaram montantes razoáveis no conjunto dos casos. Agentes de ocupações diversas, tais como 
advogados e outros profissionais liberais, prestadores de serviços, artistas, religiosos e até um banco também integram o grupo dos devedores.

Como se pode perceber, tanto do lado da oferta quanto do lado da demanda, o mercado hipotecário era bastante concentrado, embora houvesse, do lado dos devedores, categorias que claramente estavam disputando recursos, como as grandes companhias e os industriais, representantes de um setor dinâmico e importantes no contexto da transformação da economia recifense.

\section{Negociantes, bancos, capitalistas e debêntures}

$\mathrm{Na}$ sessão anterior ficou demonstrado que negociantes, bancos e capitalistas se destacaram como fornecedores de crédito. Os negociantes também foram apontados como importantes devedores. Por outro lado, não há indicação de como esses credores distribuíram seus recursos, ou onde os devedores buscavam financiamento. O lançamento de títulos ao portador também movimentou um montante considerável, embora não seja possível identificar os credores das firmas que fizeram as emissões. Verificar o comportamento desses agentes, suas práticas contratuais e quem eles financiaram é o que se fará nesta sessão.

\section{a) Negociantes ${ }^{37}$}

Até a virada republicana, a carência de intermediários financeiros que socorressem, em condições razoáveis, o pequeno comércio e as incipientes unidades industriais, os negociantes fizeram as vezes de banqueiros, assumindo o posto de principal credor da praça recifense. Desde meados da década de 1870, enquanto o setor de mercado externo enfrentava uma situação menos favorável, passaram a retrair sua participação, apesar da tendência de elevação do número de devedores e da quantidade de contratos por eles realizados, especialmente quando os bancos passaram a negociar hipotecas. Cumpre pontuar que nesse período os negociantes diminuíram ainda mais o volume de recursos disponibilizados, ampliando novamente quando da retraída na oferta dos bancos.

As condições praticadas pelos negociantes não sofreram alterações significativas ao longo do tempo. No período de fraca atuação dos bancos, no intervalo 1865-1885, cobravam juros de 13,1\% ao ano, para contratos com prazos de 13,2 meses, em média. Reduziram a taxa de juros a 11,9\% ao ano e ampliaram os prazos até 13,8 meses no intervalo 1886-1902. Entre os anos de 1903 e 1914, apesar de terem elevado os juros a 14,7\%, estenderam os prazos até 15,7 meses. Vale ressaltar que os negociantes eram os principais devedores da praça 
recifense, especialmente dos bancos. Quando os juros médios do mercado estiveram baixos, refrearam a oferta para poder captar recursos. Desse modo, tomando empréstimos a juros menores que os cobrados, para serem pagos em prazos superiores aos praticados, na média, conseguiam obter lucros razoáveis com a prática da agiotagem ${ }^{38}$.

$\mathrm{Na}$ Tabela 3 estão relacionados os 5 principais credores e os 5 principais devedores declarados negociantes, com a indicação do seu período de atuação e ramo de negócio, bem como a participação no conjunto das hipotecas.

Tabela 3 - Negociantes, valor das hipotecas e número de registros. Recife, 1865-1914.

\section{CREDORES}

\begin{tabular}{|c|c|c|c|c|}
\hline Nome & Ramo de Negócio & $\begin{array}{c}\text { Valor } \\
\text { Negociado } \\
\end{array}$ & $\%^{a}$ & $\begin{array}{c}\mathrm{N}^{\circ}{ }^{0} \text { de } \\
\text { Registros }\end{array}$ \\
\hline Mendes Lima \& Cia. (1884-1913) & Importação de bacalhau & $2.033,8$ & 2,7 & 29 \\
\hline João d'Aquino Fonseca (1890) & Importação e exportação & 735,2 & 1,0 & 1 \\
\hline Thomsen \& Cia. (1897-1901) & Importação e exportação & 582,0 & 0,8 & 3 \\
\hline Loureiro Barbosa \& Cia. (1901-1913) & Exportação & 394,2 & 0,5 & 9 \\
\hline \multirow[t]{2}{*}{ Manoel da Silva Moreira (1900-1914) } & Importação e exportação & 378,6 & 0,5 & 19 \\
\hline & Total & $4.122,8$ & 5,5 & 61 \\
\hline \multicolumn{5}{|c|}{ DEVEDORES } \\
\hline Nome & Ramo de Negócio & $\begin{array}{c}\text { Valor } \\
\text { Negociado } \\
\end{array}$ & $\%^{a}$ & $\begin{array}{c}\mathrm{N} .^{\circ} \mathrm{de} \\
\text { Registros }\end{array}$ \\
\hline A. Groshke \& Cia. (1914) & Cervejaria & $2.113,4$ & 2,8 & 1 \\
\hline Gouveia \& Cia. (1900) & Clube social & $1.394,6$ & 1,9 & 1 \\
\hline Barão de Nazareth (1876-1892) & Importação e exportação & 823,5 & 1,2 & 3 \\
\hline Augusto Octaviano de Souza (1897-1912) & Comércio varejista & 783,6 & 1,1 & 5 \\
\hline \multirow[t]{2}{*}{ Machado \& Lopes (1897-1901) } & Importação & 582,0 & 0,6 & 1 \\
\hline & Total & $5.697,1$ & 7,6 & 11 \\
\hline
\end{tabular}

${ }^{a}$ Participação relativa ao valor total das hipotecas

Fonte: Livros de Registros Hipotecários, Cartório do $1^{\circ}$ Ofício de Registro de Imóveis do Recife.

Como se pode notar, os credores estavam diretamente envolvidos nos negócios do comércio exterior. Já do lado dos devedores, apenas 2 agentes atuavam no setor de mercado externo e os demais em atividades que atendiam as demandas do setor de mercado interno. Além disso, todos eram devedores de bancos.

Destacou-se como credora a firma Mendes Lima \& Cia. A poderosa casa que iniciou seu tirocínio comercial negociando bacalhau na praça de Recife ${ }^{39}$, encabeçou 29 contratos entre os anos de 1884 e 1913, sendo 27 após 1902. Pôs em circulação o montante de 2 mil contos de réis, cerca de 3\% de todas as hipotecas negociadas no período 1865-1914. Cobrava juros anuais entre $8 \%$ e $12 \%$, em contratos com prazos que variaram entre 1 e 10 anos. 
Negociantes, especialmente os envolvidos no pequeno comércio, e proprietários eram seus principais clientes hipotecários. A casa ainda foi credora do único contrato que teve como devedor um banco. Em 29 de abril de 1904 ficou registrada a hipoteca da firma contra o Banco Popular de Pernambuco, no valor de 98,4 contos de réis, a serem pagos em 8 meses e capitalizados a $8 \%$ ao ano. Vale ressaltar que a firma ainda se aventurou no ramo dos negócios do açúcar, contraindo, junto ao Estado de Pernambuco, direitos creditórios deste contra o usineiro Joaquim José Coimbra. Os direitos correspondiam a contratos de empréstimos feitos pelo Estado de Pernambuco ao referido senhor, totalizando 2,6 mil contos de réis, garantidos com hipotecas da Usina Catende e engenho de mesmo nome, situados no município de Palmares ${ }^{40}$.

Outro agente representativo do grupo dos negociantes é o Barão de Nazareth. O nobre atuava no mercado hipotecário emprestando e tomando emprestado. Como credor, emprestou pouco mais de 136 contos de réis em 7 operações. Já como devedor, captou mais de 800 contos de réis em 3 contratos, todos junto a bancos da praça do Recife. Em um desses, a hipoteca serviu para garantir uma abertura de concordata. Entre os credores foram listados os bancos nacionais Internacional do Brasil e do Brasil, os ingleses London and Brazilian Bank e English Bank of Rio de Janeiro, além de companhias de seguro, negociantes da praça e outros não nomeados no registro. Vale pontuar, ainda, que a exata correspondência entre o número de operações e os valores emprestados pela firma norte-americana Thomsen \& Cia. com aqueles captados por Machado \& Lopes é explicada pelas relações que ambos estabeleceram um com o outro. Ao que parece, a firma que possuía armazém importador de farinha de trigo $^{41}$ não conseguiu honrar seus compromissos, uma vez que, em 1909, conforme se noticiou em periódico local ${ }^{42}$, imóveis de propriedade da firma devedora estavam sendo executados para pagamento de dívidas junto àquele credor.

Do lado dos tomadores, já ficou registrado que a maior parte dos recursos foi captada junto aos próprios negociantes. Do total acessado, quase 1/4 era devido às instituições financeiras e pouco mais de $1 / 10$ aos capitalistas. As instituições públicas se constituíram como credoras dos negociantes, em casos como a hipoteca encabeçada pela Fazenda Provincial, que no ano de 1866 aceitou um prédio residencial do senhor Justino Pereira de Faria para a garantia do pagamento do imposto do gado, no valor total de 326 contos de réis. Cabe destacar ainda o caso da firma A. Groschke \& Cia., maior devedora entre os negociantes, que captou 2,1 mil contos de réis junto à firma Kolkmann Irmãos \& Cia. e ao Banco do Recife, sem indicação de quanto tomou de cada um deles. A firma recebeu 
concessões do estado para fundar uma fábrica de cervejas de baixa fermentação e produzia bons efeitos na economia recifense ${ }^{43}$.

Em que pese os negociantes terem se colocado como importantes tomadores utilizaram mais os imóveis residenciais para lastrear os valores contratados em detrimento dos imóveis comerciais. Os imóveis e equipamentos industriais também suportaram valores significativos $(15,3 \%)$. Outros imóveis ou bens, como sítios, chácaras, terrenos e embarcações somam 5,7\%. A utilização mais expressiva de imóveis residenciais para dar suporte aos contratos demonstra que os negociantes hipotecavam outros imóveis de sua propriedade, ao invés das sedes seus escritórios ou firmas, para utilizar os créditos imobiliários na movimentação de seus negócios.

\section{b) Bancos}

Apesar da cidade do Recife dispor de um conjunto razoável de instituições especializadas na intermediação financeira, elas não atuavam com vigor no mercado hipotecário. No período discutido, apenas duas instituições realizaram destacado número de operações. Mas, de um modo geral, colocaram-se como a segunda mais importante fonte de créditos hipotecários na praça da capital pernambucana. O período de atuação mais destacada ocorreu entre os anos finais do império até a virada do século, quando se colocaram como a principal fonte de recursos da praça recifense.

$\mathrm{Na}$ Tabela 4 estão enumerados os bancos e respectivas sedes, o montante negociado e a quantidade de operações realizadas por cada um deles. Foram anotados também os períodos de atuação dos agentes, indicando-se os anos de registro da primeira e da última hipoteca.

Ao todo, 19 bancos $^{44}$ atuaram no mercado hipotecário recifense, sendo 12 nacionais e 7 estrangeiros. Dos nacionais, 8 eram sediados na capital pernambucana e os demais no Rio de Janeiro, indicando a importância do capital nativo local na formação bancária de Pernambuco e no mercado hipotecário de sua capital. Como pontuado acima, sendo a praça do Recife uma das mais importantes do Brasil, as principais instituições de atuação no território nacional, inclusive as de capital estrangeiro, ali operavam.

Entre os 5 principais credores bancários figuram 3 agentes locais. Juntos, o Banco de Crédito Real de Pernambuco, o Banco Popular de Pernambuco e o Banco de Pernambuco emprestaram pouco mais de $1 / 10$ dos valores negociados em todo o período. As maiores frações dos seus recursos foram emprestadas aos negociantes. O Banco do Brasil era o terceiro maior credor, financiando a Companhia Geral de Melhoramentos, que em 2 operações captou 1,3 mil contos de réis, e as indústrias do Recife, que levaram outros 1 mil 
contos de réis. Por fim, o grupo é encerrado pelo Banco Emissor de Pernambuco, um banco público, criado para suprir as demandas de crédito das praças de Pernambuco, Paraíba, Rio Grande do Norte e Ceará, que financiou a Companhia Beberibe e o Barão de Nazareth, importante negociante da praça recifense. Esses dados reforçam a importância do capital bancário nativo para o atendimento das demandas econômicas da cidade, socorrendo ou induzindo atividades no comércio, financiando as indústrias e a expansão da oferta de serviços públicos à população recifense.

Tabela 4 - Bancos, sedes, valor e número de registros das hipotecas. Recife, 1865-1914.

\begin{tabular}{|c|c|c|c|c|}
\hline Nome & Sede & $\begin{array}{c}\text { Valor } \\
\text { Negociado } \\
\end{array}$ & $\%^{a}$ & $\begin{array}{c}\text { N. }{ }^{\circ} \text { de } \\
\text { Registros }^{b} \\
\end{array}$ \\
\hline Banco de Crédito Real de Pernambuco (1886-1914) & Recife & $3.958,6$ & 5,60 & 286 \\
\hline Baco Popular de Pernambuco (1891-1902) & Recife & $2.783,0$ & 3,94 & 60 \\
\hline Bando do Brasil ${ }^{1}$ (1888-1894) & Rio de Janeiro & $2.548,6$ & 3,61 & 14 \\
\hline Banco de Pernambuco (1891-1900) & Recife & 858,1 & 1,21 & 7 \\
\hline Banco Emissor de Pernambuco (1891-1908) & Recife & 673,0 & 0,95 & 6 \\
\hline Augusto Frederico de Oliveira \& Cia. (1870-1883) & Recife & 373,1 & 0,53 & 12 \\
\hline English Bank of Rio de Janeiro Limited (1867-1889) & Inglaterra & 227,4 & 0,32 & 1 \\
\hline Banco do Recife (1900-1914) & Recife & 79,4 & 0,11 & 6 \\
\hline Parrs Banking Company Limited (1885) & Liverpool & 74,0 & 0,10 & 1 \\
\hline L. \& E. Wertheimber (1913) & Frankfurt & 72,7 & 0,10 & 1 \\
\hline London and River Plate Bank (1898-1910) & Londres & 72,1 & 0,10 & 4 \\
\hline $\begin{array}{l}\text { English Bank of Rio de Janeiro Limited; London and } \\
\text { Brazilian Bank Limited }^{2}(1874)\end{array}$ & Inglaterra & 62,9 & 0,09 & 1 \\
\hline London and Brazilian Bank Limited (1867-1874) & Londres & 54,1 & 0,08 & 1 \\
\hline Frey \& Mier (1876) & Londres & 40,7 & 0,06 & 1 \\
\hline Banco Internacional do Brasil (1887-1889) & Rio de Janeiro & 17,4 & 0,02 & 1 \\
\hline Banco Sul Americano (1890) & Rio de Janeiro & 15,3 & 0,02 & 2 \\
\hline Banco Industrial e Mercantil do Rio de Janeiro (1879) & Rio de Janeiro & 14,8 & 0,02 & 1 \\
\hline Caixa Econômica e Monte de Socorro do Recife (1877) & Recife & 13,7 & 0,02 & 1 \\
\hline Banco das Classes (1902) & Recife & 7,3 & 0,01 & 1 \\
\hline Caixa de Crédito Industrial (1877) & Portugal & 0,9 & 0,00 & 1 \\
\hline Total & & $11.874,4$ & & 408 \\
\hline
\end{tabular}

${ }^{a}$ Participação relativa ao valor total das hipotecas.

${ }^{\mathrm{b}}$ As instituições Banco Internacional do Brasil, London and Brazilian Bank Limited, English Bank of Rio de Janeiro e Banco do Brasil, foram credoras em 1 operação junto a outros agentes, assim como o Banco do Recife. Mas não havia, nos registros, indicação do valor que cabia a cada um dos agentes, impossibilitando a inclusão desses valores no cômputo geral dos valores emprestados pelos bancos. Por esse motivo, alguns desses bancos, que foram relacionados como tendo realizado apenas 1 operação, estão com um período maior que 1 ano de atuação.

${ }^{1}$ Banco do Brasil e Banco da República do Brasil juntos.

${ }^{2} \mathrm{O}$ empréstimo foi realizado em letras dos bancos, mas sem a indicação de quanto cabia a cada um deles.

Fonte: Livros de Registros Hipotecários, Cartório do $1^{\circ}$ Ofício de Registro de Imóveis do Recife.

Comentou-se acima a respeito da melhoria das condições dos empréstimos em função do ingresso dos bancos no mercado hipotecário. No interior desse conjunto também ocorreram mudanças nas condições ao longo do tempo, que pode ser explicada pela mudança no perfil geral dos bancos que negociavam hipotecas. No período 1865-1885, os bancos eram fundamentalmente comerciais, e as condições praticadas no período denotam essa característica: prazos em torno de 12 meses, com os valores capitalizados a 11,5\% ao ano, em 
média. Já no período posterior, de 1886 a 1914, havia bancos de distintos perfis, como os comerciais, os universais e os de crédito real. Alguns bancos fizeram empréstimos com prazos bastante curtos e juros mais elevados, mas na média, os prazos giraram em torno dos 12 anos e os juros se situaram na casa dos $8,3 \%$ anuais.

O Banco do Brasil, por exemplo, praticava condições diferenciadas, a depender o valor do contrato. Metade das hipotecas encabeçadas pelo dito banco tinha como devedores agentes que se declararam lavradores. Mas estes acessaram apenas $1 \%$ dos recursos disponibilizados, nas condições idênticas às praticadas contra os negociantes: prazos de 2 anos e juros de $6 \%$ ao ano. Por outro lado, em apenas 3 registros, o Banco do Brasil pôs em circulação mais de 4/5 de todo o crédito disponibilizado em sua carteira hipotecária no Recife, capitalizados a 7\% ao ano e com prazos de até 15 anos para amortização. O Banco Popular de Pernambuco, outra importante fonte de recursos, também praticava condições diferenciadas conforme o valor da hipoteca, no geral aproximadas do crédito comercial, cobrando juros médios de $11 \%$ ao ano em contratos a serem pagos, em média, dentro de 12 meses.

As condições mais razoáveis e estáveis eram praticadas pelo Banco de Crédito Real de Pernambuco, que cobrou juros médios de 7,6\% ao ano, em contratos com prazo médio superior a 15 anos. Note-se que a especialidade do Banco de Crédito Real de Pernambuco se concentraria em empréstimos de valores não inferiores a 5 contos de réis, garantidos com bens imóveis, amortizados em anuidades, contratados por prazos não inferiores a 10 anos e capitalizados a juros de $7 \%$ anuais mais $1 \%$ de comissão ${ }^{45}$. Como realizou quase $3 / 4$ dos contratos encabeçado pelos bancos, nos quais se emprestou 1/3 dos recursos com origem em instituições financeiras, as condições praticadas pelo Banco de Crédito Real de Pernambuco influenciaram sobremaneira os valores médios dos prazos e das taxas de juros cobradas, explicando o alargamento dos prazos e o rebaixamento dos juros.

As figuras dos proprietários e dos negociantes integravam as maiores clientelas dos bancos, estando ainda os lavradores, os profissionais liberais, os funcionários públicos, os advogados, os industriais e os capitalistas entre os clientes mais frequentes. Por outro lado, as maiores frações foram captadas pelos negociantes, pela Companhia Geral de Melhoramentos em Pernambuco, pelos proprietários e pelos industriais. Lavradores, profissionais liberais e capitalistas integram a lista dos que tomaram valores significativos.

Do montante disponibilizado pelos bancos, mais da metade foi garantido com imóveis residenciais. Propriedades de firmas industriais, inclusive 4 engenhos, assim como prédios comerciais, sítios e chácaras e terrenos, também serviram para lastrear os contratos. 
c) Capitalistas

Os capitalistas não realizaram muitas operações logo após a reforma hipotecária, tendo sua atuação mais destacada iniciado na década de 1880. Retraíram a oferta nos anos do Encilhamento, mas logo retomaram os empréstimos, ampliando progressivamente sua atuação até os anos de transição entre os séculos XIX e XX. Após esse período, arrefeceram os negócios, encerrando o período no patamar alcançado ainda na década de 1870.

As práticas contratuais dos capitalistas tenderam a um endurecimento ao longo do tempo, sobretudo no que se refere ao encurtamento dos prazos de quitação dos empréstimos. No intervalo 1865-1885, cobravam juros médios em torno de 15,3\% em hipotecas que deveriam ser quitadas em 16,6 meses. No período seguinte, enquanto os negociantes rebaixaram os juros e ampliaram os prazos, os capitalistas fizeram exatamente o contrário: encurtaram os prazos a 14,5 meses e elevaram os juros $16,2 \%$, endurecendo ainda mais as condições entre 1903-1914, quando ajustaram os prazos para 12 meses, mantendo os juros na casa dos $16,4 \%$.

Em que pese ter realizado um número de contratos próximo ao dos negociantes, o grupo dos capitalistas era menos diverso, composto por 81 homens e 6 mulheres que assim se autodeclararam. As mulheres movimentaram $1,1 \%$ dos valores em 10 contratos. Na Tabela 5 estão listados os principais credores declarados capitalistas, indicados seu período de atuação, bem como o montante por eles emprestado e a representação desse montante na soma geral, além do número de contratos realizados.

Tabela 5 - Capitalistas, valor das hipotecas e número de registros. Recife, 1865-1914.

\begin{tabular}{|c|c|c|c|}
\hline Nome & $\begin{array}{c}\text { Valor } \\
\text { Negociado }\end{array}$ & $\%^{a}$ & $\begin{array}{c}\text { N. }{ }^{\circ} \text { de } \\
\text { Registros } \\
\end{array}$ \\
\hline Thomaz Comber (1882-1906) & $1.915,6$ & 2,6 & 228 \\
\hline Victorino Domingos Alves Maia (1873-1895) & 553,9 & 0,7 & 108 \\
\hline João Gonçalves da Fonseca (1896-1910) & 407,3 & 0,5 & 64 \\
\hline Antonio José de Sousa (1873-1882) & 347,9 & 0,5 & 26 \\
\hline Marcelino José Baptista (1898-1914) & 259,1 & 0,3 & 63 \\
\hline Gratuliano dos Santos Vital (1882-1895) & 216,2 & 0,3 & 26 \\
\hline Francisco Gonçalves Netto (1879-1888) & 215,5 & 0,3 & 6 \\
\hline Joaquim Manoel Ferreira de Sousa (1867-1889) & 182,9 & 0,2 & 21 \\
\hline João Baptista Pereira de Souza (1909-1913) & 178,4 & 0,2 & 17 \\
\hline Albino José da Silva (1873-1901) & 174,3 & 0,2 & 9 \\
\hline To & $4.451,1$ & 5,8 & 568 \\
\hline
\end{tabular}

${ }^{a}$ Participação relativa ao valor total das hipotecas.

Fonte: Livros de Registros Hipotecários, Cartório do $1^{\circ}$ Ofício de Registro de Imóveis do Recife. 
Dois agentes se destacaram pelo tamanho da clientela. Um esteve à frente de mais de 2 centenas de operações e outro emprestando mais de 100 vezes. Esses dois credores foram responsáveis por pouco mais de 1/3 dos contratos e dos valores negociados pelos capitalistas. São os senhores Thomaz Comber e Victorino Domingos Alves Maia. A atuação desses agentes ocorreu em momentos distintos, tendo um período de concorrência entre ambos. $\mathrm{O}$ senhor Victorino Domingos Alves Maia, que tocava um armazém de carne seca e detinha diversos imóveis nas freguesias urbanas do Recife, realizou 108 hipotecas entre os anos de 1873 e 1895. A partir do ano de 1882, passou a sofrer a concorrência do senhor Thomaz Comber. Este, natural da Bahia, onde havia ingressado no mundo dos negócios, manteve participação ativa na vida econômica de Pernambuco, como membro da diretoria da Associação Comercial Beneficente ${ }^{46}$, como integrante da comissão que organizou e dirigiu o Banco de Pernambuco ${ }^{47}$, incorporador, sócio e diretor de empresas na praça recifense, com atuação especial no comércio de importação e exportação. Figurou nos registros como credor hipotecário até 1906, realizando 228 contratos, revelando-se o segundo maior credor em termos de contratos celebrados, atrás apenas do Branco de Crédito Real de Pernambuco.

Os contratos foram preferencialmente suportados com imóveis residenciais. Ainda foram aceitos sítios, chácaras e terrenos, bens industriais, inclusive engenhos, imóveis comerciais e até mesmo embarcações. Ao que parece, o crédito ofertado pelos capitalistas serviu para induzir a expansão imobiliária da cidade e o comércio varejista, socorrendo ainda o setor de mercado externo.

\section{d) Debêntures}

Como anotado na Tabela 2, o lançamento de títulos garantidos com hipoteca não era um recurso usual no mercado recifense. A primeira operação dessa natureza ocorreu em 1885, revelando-se a maior de todo o período, mobilizando recursos superiores aos transacionados na maioria dos anos analisados. Nela, a Companhia Beberibe, responsável pelo abastecimento de água na cidade desde a primeira metade do século XIX buscou captar a importância de 2,5 mil contos de réis nominais, oferecendo como garantia diversos bens imóveis de propriedade da companhia, inclusive o Engenho Dois Irmãos, com todas as suas obras e terras ${ }^{48}$. A referida companhia usou do mesmo expediente para se capitalizar em 6 oportunidades entre os anos de 1885 e 1896, além de obter um empréstimo junto ao Banco Emissor de Pernambuco no ano de 1891. Captou, ao todo, 6,9\% de todo o montante disponibilizado no período 1865-1914. Dispôs sempre do mesmo conjunto de bens para garantir os contratos, nos quais acertou o pagamento de $6 \%$ de juros sobre os títulos. 
No quadro geral, aos futuros obrigacionistas, portadores dos títulos emitidos pelas companhias devedoras, fora acordada a remuneração sobre o valor nominal dos títulos que possuíssem a uma taxa anual média de $7,1 \%$, com operações chegando a prometer o pagamento de juros na casa dos $10 \%$ anuais. Este foi o caso da Companhia Manufatora de Phosphoros, firma organizada pelo senhor Antonio Baltar, que fez o lançamento de títulos em 1898, para captar a importância de 200 contos de réis nominais. O pagamento dos títulos era normalmente realizado por sorteio. O prazo médio de validade desses títulos era de pouco mais de 18 anos, nunca menos que 10 anos, e nesse meio tempo os detentores das obrigações se colocavam como proprietários, na parte que lhes cabiam o conjunto dos títulos que possuíam, dos bens daquelas empresas.

$\mathrm{Na}$ Tabela 6 estão relacionadas as 11 firmas que realizaram 19 operações de lançamento de debêntures garantidas com hipotecas. Eram 4 tecelagens, 2 de serviço público (água e trens urbanos), 2 clubes, 1 de transporte marítimo e 1 refinaria.

Tabela 6 - Firmas, número de registros e valor das hipotecas realizadas com a emissão de debêntures. Recife, 1865-1914.

\begin{tabular}{|c|c|c|c|c|}
\hline Nome & Atividade & $\begin{array}{c}\text { Valor } \\
\text { Negociado }\end{array}$ & $\%^{a}$ & $\begin{array}{c}\text { N. }{ }^{\circ} \text { de } \\
\text { Registros }\end{array}$ \\
\hline Companhia Beberibe (1885-1896) & Abastecimento de água & $5.128,5$ & 6,9 & $\overline{6}$ \\
\hline $\begin{array}{l}\text { Companhia Pernambucana de Navegação a Vapor } \\
(1887-1889)\end{array}$ & Navegação & $1.846,3$ & 2,5 & 2 \\
\hline Companhia Norte Brazil (1911) & Tecidos & $1.281,2$ & 1,7 & 1 \\
\hline Braz Silva \& Cia. (1896-1913) & Tecidos & 435,1 & 0,6 & 2 \\
\hline Companhia Fábrica de Estopa (1894) & Tecidos & 252,2 & 0,3 & 1 \\
\hline $\begin{array}{l}\text { Companhia de Trilhos Urbanos do Recife a } \\
\text { Olinda e Beberibe (1889-1894) }\end{array}$ & Trens urbanos & 200,7 & 0,3 & 2 \\
\hline $\begin{array}{l}\text { Companhia Nacional de Camisas e Roupas } \\
\text { Brancas (1895) }\end{array}$ & Tecidos & 184,3 & 0,2 & 1 \\
\hline Companhia Manufatora de Phosphoros (1898) & Fósforos & 141,5 & 0,2 & 1 \\
\hline Club Internacional do Recife (1914) & Clube social & 138,3 & 0,2 & 1 \\
\hline $\begin{array}{l}\text { Companhia Refinaria e Destilação Pernambucana } \\
\text { (1894) }\end{array}$ & Açúcar & 134,5 & 0,2 & 1 \\
\hline Empresa do Hipódromo do Campo Grande (1889) & Clube social & 46,4 & 0,1 & 1 \\
\hline & Total & $9.789,0$ & 13,2 & 19 \\
\hline
\end{tabular}

${ }^{a}$ Participação relativa ao valor total das hipotecas.

Fonte: Livros de Registros Hipotecários, Cartório do $1^{\circ}$ Ofício do Registro de Imóveis do Recife.

Em que pese a Companhia Pernambucana de Navegação a Vapor se colocar como a segunda maior devedora de hipotecas inscritas para a garantia de debêntures, foi a Companhia Norte Brazil, manufaturadora de morins e chitas, sediada no Rio de Janeiro, que realizou o segundo maior lançamento de títulos em uma operação, na qual prometeu pagar $8 \%$ de juros sobre o valor nominal dos títulos. A companhia foi formada em 1911, mesmo ano de inscrição da hipoteca, e garantiu o contrato com os terrenos onde estavam sendo construídos 
os edifícios da fábrica. Se for desconsiderada a hipoteca na qual a Companhia Beberibe buscou captar 2,5 mil contos de réis nominais, o conjunto das tecelagens movimentou a maior soma entre as firmas que lançaram debêntures na praça do Recife. As 5 operações somam 2.152,8 contos de réis.

Ainda merecem menção os lançamentos de debêntures realizados pela firma Braz Silva \& Cia. A empresa atuava no ramo têxtil e era proprietária da Fábrica de Apipucos, fundada em 1895, que serviu como garantia dos títulos. As duas transações totalizaram 435 contos de réis, capitalizados a juros de 8\% (135 contos de réis, captados em 1896) e 7\% (300 contos de réis, captados em 1913). A empresa ainda era beneficiária da política econômica do governo provincial, tendo recebido o privilégio, em 1899, de isenção de impostos por 3 anos sobre os produtos que fabricava ${ }^{49}$.

Note-se que as operações ocorreram, em sua maioria, na última década do século XIX, quando o Recife experimentava a expansão do seu parque industrial. Mesmo não sendo um recurso usual, esses registros indicam a crescente importância que o departamento industrial vinha assumindo na economia do Recife. Apesar das ocorrências pontuais, sua importância se deve aos elevados valores que foram movimentados nas transações, evidenciando os fortes investimentos que a cidade recebeu para promover sua reestruturação produtiva. Tomando como referência todo o período em questão (1865-1914), os debenturistas formaram o terceiro maior grupo de credores hipotecários. Esses recursos serviram para induzir a industrialização do Recife e ampliar a oferta de serviços urbanos, especialmente o abastecimento de água potável e o transporte público.

\section{Considerações Finais}

$\mathrm{Na}$ descrição do quadro geral da formação econômico-social do Recife, foram sugeridos indicativos preliminares das formações dos grupos credores e devedores do mercado hipotecário recifense, e das possibilidades de configuração dos arranjos ou circuitos de empréstimos. Após aprofundar a análise das características específicas do mercado, foi confirmada a proeminência dos negociantes, tanto como credores quanto como devedores. Como estes realizaram operações junto aos bancos, captando desta fonte um montante razoável de recursos, confirmou-se, ainda, que os principais abastecedores da praça hipotecária do Recife eram os negociantes e os bancos, aqueles ocupando o lugar mais importante na ausência destes. De outro lado, com um setor industrial em desenvolvimento, esses agentes se colocaram como destinos atrativos para as aplicações. Ainda que a população 
recifense não tenha apresentado uma taxa de crescimento expressiva, sua evolução demográfica cria demanda por moradia. Esse fato, sugestivo da utilização dos créditos imobiliários para a movimentação dos negócios no Recife, também ficou evidente, pois os imóveis residenciais compuseram a categoria preferencial para lastrear os contratos.

Os resultados do procedimento de análise dos registros hipotecários da praça da capital pernambucana revelaram um mercado pouco dinâmico, que não sofreu fortes influências do crescimento demográfico da cidade do Recife, de capitais de fora e nem mesmo da expansão monetária ocorrida na transição republicana. Por outro lado, as operações ocorreram com certa regularidade, com ciclos de ânimo e recessão, determinados pelas oportunidades criadas pelas condições estruturais da economia regional. No plano geral, as práticas contratuais dos agentes apresentaram uma melhoria sensível nas condições do financiamento, especialmente patrocinada pelas instituições financeiras.

Apesar da hipoteca não ter sido uma inovação no tocante a oferta de crédito, a reforma na legislação ocorrida em meados da década de 1860 possibilitou uma expansão no mercado, maior em termos de número de operações do que no valor disponibilizado. Mesmo que dispositivos legais posteriores não tenham surtido o efeito esperado na praça do Recife, alguns dos agentes, especialmente aqueles que desempenhavam as atividades mais dinâmicas, estavam atentos às inovações institucionais e ali buscaram captar recursos necessários à indução de processos de desenvolvimento da economia recifense, como atestam as participações das indústrias, de grandes companhias e de empresas de serviços públicos nos montantes captados, inclusive por meio do lançamentos de títulos no mercado financeiro.

A despeito da diminuição do ritmo de crescimento da economia pernambucana no século XIX, oportunidades de avanço continuaram existindo. Alguns setores, como o comércio e a indústria, realizaram investimentos e contribuíram para manter ativa a praça recifense. Assim, de um modo geral, o crédito hipotecário recifense não refletiu os resultados decrescentes das exportações de Pernambuco, mas serviu para induzir uma série de investimentos que patrocinaram a transformação de sua estrutura produtiva, aprofundando o descolamento das atividades vinculadas ao setor de mercado externo, para atender as demandas do mercado interno.

A análise de perfil indicou que as principais fontes do crédito ofertado advieram de poupanças nativas e foram aplicados na própria economia recifense, indicando um crédito iminentemente local, que não demandou capital externo, em que pese setores dinâmicos terem despertado seu interesse. Os capitais de fora do Recife foram disponibilizados, em sua maior fração, por bancos com atuação no território nacional e que possuíam caixas filiais na cidade. 
De um modo geral, o crédito hipotecário foi utilizado para dar suporte à expansão urbana da cidade, inclusive sua rede de serviços públicos, e patrocinar uma reestruturação produtiva, com investimentos nas indústrias e fortalecimento do comércio.

Em que pese os bancos terem se colocado como uma das mais importantes fontes de recursos entre os anos finais do império e a virada do século, foram usurários ou rentistas locais que compuseram a maior fração das poupanças colocadas à disposição da economia do Recife. Ao que parece, as atividades em torno do açúcar e do algodão lograram condições para que se acumulasse capital ao longo do tempo, que foram reunidos e formaram o crédito hipotecário negociado na praça da capital pernambucana, tanto individualmente quanto por intermédio das instituições financeiras nativas.

\footnotetext{
${ }^{1}$ Ultrapassa os limites deste estudo a análise das questões que implicaram na perda de competitividade do açúcar brasileiro frente aos seus sucedâneos e a consequente perda de seu espaço no mercado mundial. Para melhores explicações, ver Eisenberg (1977) e Ferlini (1994), por exemplo. A cotonicultura, por sua vez, também foi muito importante para a economia pernambucana, chegando mesmo, em alguns episódios, a superar as exportações de açúcar. Sem se referir às Guerras da Independência (1776-1783) e de Secessão (1860-1864) nos Estados Unidos, De Carli (1938) faz menção a ascensão do algodão como importante tributário do desenvolvimento econômico do Nordeste, e de Pernambuco, em especial, naqueles interstícios. Singer (1977), por outro lado, atribui àqueles conflitos a emergência da cultura do algodão brasileiro como abastecedor do mercado britânico, exportado, em grande parte, pelo porto do Recife.

${ }^{2} \mathrm{O}$ marco regulatório do crédito hipotecário veio por meio da Lei n. ${ }^{\circ} 1.237 / 1864$ e do Decreto n. ${ }^{\circ} 3.453 / 1865$. A política dos engenhos centrais foi institucionalizada pelo Decreto n. $.^{\circ} 2.687 / 1875$, que também garantiu juros às sociedades de crédito real que se formassem de acordo com a Lei da Hipotecas. Já o Decreto n. ${ }^{\circ} 3.272 / 1885$ buscou estimular o mercado de capitais, autorizando bancos e sociedades de crédito real a fazerem empréstimos de prazos curtos sob penhor de acessórios não compreendidos nas hipotecas. Na virada republicana, um pacote institucional, consagrado na história como Encilhamento, buscou incrementar o meio circulante disponível, autorizando a formação de bancos com poder de emitir moeda. Por fim, os Decretos de n. ${ }^{\circ} 169-\mathrm{A} / 1890$ e n. ${ }^{\circ}$ 370/19890 definiram a nova legislação hipotecária.

3 A literatura sobre o tema tem se avolumado nas últimas décadas. Ver, por exemplo, Sweigart (1980), Marcondes (2002), Brito (2006), Pires (2006), Almico (2009; 2015), Marcondes; Hanley (2010), Cortes; Marcondes; Diaz (2011), Fontanari (2011), Marcondes (2014), Leandro; Marcondes; Silva (2015), Leandro (2015).

${ }^{4}$ Agradecemos imensamente a Dra. Miriam de Holanda Vasconcelos, tabeliã do cartório, por facilitar o acesso aos registros, bem como oferecer uma estrutura completa para a coleta dos dados. Agradecemos também aos funcionários do cartório que nos auxiliaram no manuseio das fontes e na leitura dos registros, especialmente aos senhores Jair, Daniel, Mirinaldo, Romualdo e Carlos. O $2^{\circ}$ Ofício de Registro de Imóveis do Recife foi instalado somente em 1956, o equivale a dizer que o conjunto dos contratos de crédito analisados corresponde ao universo das hipotecas registradas na Comarca do Recife no período.

${ }^{5}$ Foram utilizados, basicamente, relatórios provinciais e almanaques de Pernambuco em tal observação. Cumpre esclarecer que tais fontes não são representações fidedignas do conglomerado de agentes que desempenham atividades econômicas nos diversos setores. Mas podem oferecer evidências consistentes para que observe, em paralelo a outros dados, a evolução socioeconômica da cidade. Nos almanaques constam listas de estabelecimentos classificados por ramo de atividade, enquanto nos relatórios provinciais podem ser coletadas informações a respeito de estabelecimentos dignos da atenção dos governantes ou que eventualmente negociavam com os governos ou eram beneficiários das políticas governamentais. Tal procedimento metodológico é completado com o cruzamento com outras fontes, como jornais da época e o repertório da legislação imperial e republicana. Recurso semelhante foi sugerido por Andrade (1973), e utilizado por Singer (1977) e Domingues (2000), por exemplo.

${ }^{6}$ Decreto n. ${ }^{\circ} 2.687 / 1875$.

${ }^{7}$ Para manter a unidade territorial, as populações de Jaboatão, Muribeca e São Lourenço da Mata não foram incluídas no cálculo.

${ }^{8}$ Almanak Administrativo, Mercantil e Industrial da Província de Pernambuco, 1864.
} 


\footnotetext{
${ }^{9}$ Almanak Administrativo, Mercantil, Agrícola e Industrial do Estado de Pernambuco, 1894.

${ }^{10}$ Almanak Administrativo, Mercantil e Industrial da Província de Pernambuco, 1864.

${ }^{11}$ Almanak Administrativo, Mercantil, Agrícola e Industrial do Estado de Pernambuco, 1894.

12 Costa (1923) pontuou que muitas terras de engenhos situados nas margens do rio Capibaribe, na segunda metade do século XIX, foram loteadas, dando origens a sítios e chácaras que serviam de locais de veraneio para a classe mais abastada da cidade. Com o avanço da malha urbana, esses locais de temporada acabaram se tornando moradias fixas.

${ }^{13}$ Os dados sugerem uma aparente retração da atividade industrial em função da diminuição do número de estabelecimentos de 103 para 55 unidades entre os anos de 1864 e 1907. Todavia, cumpre esclarecer que algumas das unidades relacionadas nos almanaques do século XIX correspondiam a pequenas fábricas, como por exemplo, de calçados, de móveis ou de instrumentos musicais, não se constituindo, portanto, em unidade industrial propriamente dita, mas em oficinas que comercializavam mercadorias manufaturadas na unidade.

${ }^{14}$ Para uma análise do processo de industrialização de Pernambuco, ver Domingues (2000), por exemplo.

${ }^{15}$ Ver "O Recife de Hontem", Jornal Pequeno, n. ${ }^{\circ}$ 55, 07/03/1929.

${ }^{16}$ A instalação da caixa filial no Recife foi aprovada pelo Decreto n. ${ }^{\circ} 1.580 / 1855$.

${ }^{17}$ O Decreto n. ${ }^{\circ}$ 2.979/1862 permitiu a instalação do banco no Brasil. As operações no Recife foram autorizadas pelo Decreto 3.102/1863. Diário de Pernambuco, 30/07/1863.

${ }^{18}$ Permitida sua instalação no Brasil pelo Decreto n. ${ }^{\circ} 3.212 / 1863$, a agencia no Recife foi autorizada pelo Decreto 3.796/1867. Diário de Pernambuco, 02/07/1867.

${ }^{19}$ Jornal do Recife, 18/01/1865.

${ }^{20}$ Almanak Administrativo, Mercantil e Industrial da Província de Pernambuco, 1864.

${ }^{21}$ Jornal do Recife, 25/01/1875.

${ }^{22}$ Jornal Pequeno, 07/03/1929.
}

${ }^{23}$ Em 1882, houve a tentativa de formação do Banco de Crédito Real Agrícola (Diário de Pernambuco, 22/06/1882), e em 1883, a Sociedade Auxiliadora de Agricultura de Pernambuco tentou criar o Banco Auxiliar da Agricultura (Diário de Pernambuco, 27/05/1883).

${ }^{24}$ Autorizada a incorporação pelo Decreto n. ${ }^{\circ} 9.457 / 1885$, que também aprovou seus estatutos, no ano seguinte o banco iniciou suas operações.

${ }^{25}$ Teve os estatutos aprovados pelo Decreto n. ${ }^{\text {3 } 367-A / 1890, ~ e ~ a l t e r a d o s ~ p e l o ~ D e c r e t o ~ n . ~}{ }^{\text {o } 395 / 1890 . ~}$

${ }^{26}{\text { Teve seus estatutos aprovados pelo Decreto n. }{ }^{\circ} 880 / 1890 .}^{27}$

${ }^{27}$ Bancos relacionados nos livros de registros hipotecários consultados.

${ }^{28}$ Almanak Administrativo, Mercantil, Agrícola e Industrial do Estado de Pernambuco, 1894.

${ }^{29}$ A Província, 20/06/1900.

${ }^{30}$ Bancos relacionados nos livros de registros hipotecários consultados.

${ }^{31}$ Estabelecido em 1862, com sede na Inglaterra, sob a denominação The London, Buenos Ayres and River Plate Bank Limted, foi autorizado a estabelecer caixas filiais no território da república pelo Decreto n. ${ }^{\circ}$ 591/1891.

32 A dívida hipotecária pernambucana consolidada para o período 1855-1859 totalizou 2.243 contos de réis nominais, sendo que quase $60 \%$ daquela dívida (1.295 contos de réis) estava gravada na comarca da capital. Entre 1865 e 1869, após a reforma hipotecária, a dívida inscrita no Recife contabilizou 2,9 mil contos de réis nominais (equivalentes a 4,3 mil contos de réis em valor real). Ver Brasil (Ministério da Justiça). Ministro (João Lustosa da Cunha Paranaguá). Relatório. 14/05/1860. Relatorio do Ministerio da Justiça, apresentado á Assembléa Geral Legislativa na quarta sessão da decima legislatura pelo respectivo ministro e secretario de estado João Lustosa da Cunha Paranaguá. Rio de janeiro: Typographia Nacional, 1860. Disponível em <http://brazil.crl.edu/bsd/bsd/u1851/> e Acesso em 13/11/2017.

${ }^{33}$ As séries foram deflacionadas a partir dos indicadores de Goldsmith (1986) para o período de 1865-1869, de Catão (1992) para o intervalo 1870-1913, e de Haddad (1978) para o ano de 1914. A menos que se expresse o contrário, todos os valores descritos daqui adiante são valores reais.

${ }^{34}$ Em São Paulo e no Rio de Janeiro (Distrito Federal), houve um incremento significativo da oferta de crédito no mercado hipotecário. Ver, por exemplo, Marcondes (2014). Apesar de não dispor dos microdados referentes ao período do Encilhamento, o estudo de Leandro (2015) sugere uma tendência de elevação na oferta de crédito na praça de Belém até o final do século XIX e a forte contração do início do século XX.

${ }^{35} \mathrm{O}$ banco realizou 6 operações entre os anos de 1891 e 1908, movimentando 672,9 contos de réis.

${ }^{36}$ Apenas a hipoteca do engenho Gurjahu de Cima, de propriedade da abastada família Sousa Leão, na qual o senhor Manoel de Sousa Leão captou 51 contos de réis junto a José de Sousa Leão, entre outros bens, ofereceu um plantel de 60 escravos.

${ }^{37}$ Há certa dificuldade em proceder a uma caracterização precisa do grupo dos negociantes, composto por pessoas físicas e jurídicas, além de apresentar diferenciações internas, desde os ditos de grosso trato, aplicados na importação e exportação, até aqueles que tocavam pequenos estabelecimentos para venda de mercadorias a 
retalho. Uma boa caracterização do grupo dos negociantes, abordando sua constituição histórica e diferenciações internas, foi elaborada por Dourado (2015).

${ }^{38}$ Em artigo no periódico A Província, da edição de 10/05/1891, lê-se "A grande massa de comerciantes a retalho, os representantes de indústrias importantes não pensavam se quer em transigir com os bancos para facilitar suas transações, ou desenvolver a sua actividade. Só os milionários tinham crédito, porque a cofiança que o determinava se entendia ser exclusivamente emanada da certesa de fortuna já acumulada. Comprehendese o florescimento da agiotagem nos períodos anteriores".

${ }^{39}$ Almanak Administrativo, Mercantil, Industrial e Agrícola da Província de Pernambuco, 1881.

${ }^{40}$ Pernambuco (Estado). Governador (Sigimundo Antonio Gonçalves). Mensagem. 06/03/1906. Mensagem do Exm. Sr. Desembargador Sigsmundo Antonio Gonçalves, governados do estado, lida por occasião da installação da terceira sessão ordinária da $5^{a}$ legislatura do Congresso Legislativo do Estado, aos 6 de março de 1906. Recife: Typographia do Diario de Pernambuco, 1906. Disponível em <http://brazil.crl.edu/bsd/bsd/u2375/> e Acesso em 13/11/2017.

${ }^{41}$ Diário de Pernambuco, 30/03/1900, sessão Indicador Comercial, p. 5.

42 Diário de Pernambuco, 27/11/1909, p. 4.

${ }^{43}$ Pernambuco (Estado). Governador (Manoel Antonio Pereira Borba). Mensagem. 06/03/1918. Mensagem do Exm. Sr. Dr. Manoel Antonio Pereira Borba, governador do Estado de Pernambuco, lida por occasião da installação da $3^{a}$ sessão da $9^{a}$ legislatura do Congresso Legislativo do Estado aos 6 de março de 1918. Pernambuco: Officinas da Impensa Official, 1918. Disponível em <http://brazil.crl.edu/bsd/bsd/u2390/> e Acesso em 13/11/2017.

${ }_{44}$ O Banco do Brazil e o Banco da República do Brazil foram contabilizados como Banco do Brasil.

${ }^{45}$ Jornal do Recife, 06/01/1886, p. 2.

${ }^{46}$ Jornal do Recife, 17/03/1876, p. 2.

${ }^{47}$ Pernambuco (Província). Vice-Presidente (Manoel Alves de Araújo). Relatório. 14/11/1889, p. 34. Relatório com que o Exm. Sr. Manoel Alves de Araújo entregou a administração da província ao Exm. Sr. Dr. Sigismundo Antonio Gonçalves, em 14 de novembro de 1889. Recife: Typ. de Manoel Figueiros de Faria \& Filhos, 1890. Disponível em <http://brazil.crl.edu/bsd/bsd/u675/> e Acesso em 13/11/2017. Jornal do Recife, 15/02/1890, p. 1.

48 No Engenho Dois Irmãos estava localizado um importante manancial de água potável que serviu ao abastecimeto da cidade do Recife. Para compreender o contexto histórico da aquisição do engenho pela Companhia Beberibe, ver Jucá (1975).

49 Jornal Pequeno, 5/10/1899, p. 2.

\section{Referências Bibliográficas}

ALBUQUERQUE, Débora de Souza Leão. A macroeconomia pernambucana no século XIX. Economia e Desenvolvimento. Recife, v. 13, n. 1, 2014, p. 111-129.

ALMICO, Rita de Cássia da Silva. Dívida e obrigação: as relações de crédito em Minas Gerais, séculos XIX/XX. Tese (Doutorado em História) - Universidade Federal Fluminense, Niterói, 2009.

. Em nome da palavra e da lei: relações de crédito em Minas Gerais nos Oitocentos. Rio de Janeiro: 7 letras, 2015. 273p.

ANDRADE, Manuel Correia de. O Recife e o desenvolvimento da região nordestina. Estudos Universitários. Recife, 13(2-3), abr./set., 1973, p. 117-162.

BRITO, Mônica Silveira. Modernização e tradição: urbanização, propriedade da terra e crédito hipotecário em São Paulo, na segunda metade do século XIX. Tese (Doutorado em Geografia) - Faculdade de Filosofia, Letras e Ciências Humanas, Universidade de São Paulo, São Paulo, 2006.

CATÃO, Luis A. V. A new wholesale price index for Brazil during the period 1870-1913. Revista Brasileira de Economia. Rio de Janeiro, FGV, 46(4), out./dez., 1992, p. 519-533.

CORTES, Gustavo da Silva; MARCONDES, Renato Leite; DIAZ, Maria Dolores Montoya. Beyond Banks and Stocks: a study of industrial mortgages for the City of São Paulo, Brazil (1866-1914). In: ANPEC XXIX, 2011, Foz do Iguaçu. Anais. Foz do Iguaçu: ANPEC, 2011. 
COSTA, Francisco Augusto Pereira da. Os arredores do Recife. Rev. Insti. Arq. Hist. Geog. Pern. Recife, 25(119-122), jan./dez., 1923, p. 10-150.

DE CARLI, Gileno. Geografia economica e social da canna de açucar no Brasil. Edição de Brasil Açucareiro, 1938. 109 p.

DOMINGUES, Luís Manuel. O processo de industrialização em Pernambuco (1890-1920). Revista Symposium. Recife, UNICAP, 4(1), jan./jun., 2000, p. 57-76.

DOURADO, Bruna Iglezias Motta. Comércio de grosso trato e interesses mercantis no Recife, Pernambuco (c. $1837-c$. 1871): a trajetória do negociante João Pinto de Lemos. Dissertação (Mestrado em História) - Instituto de Ciências Humanas e Filosofia, Universidade Federal Fluminense, Niterói, 2015.

EISENBERG, Peter L. Modernização sem mudança: a indústria açucareira em Pernambuco (1840-1910). São Paulo: Paz e Terra, 1977. 294p.

FERLINI, Vera Lúcia Amaral. A civilização do açúcar (século XVI a XVIII). São Paulo: Brasiliense, 1994. 101p.

FONTANARI, Rodrigo. O problema do financiamento: uma análise histórica sobre o crédito no complexo cafeeiro paulista. Casa Branca (1874-1914). Dissertação (Mestrado em História) - Faculdade de Ciências Humanas e Sociais, Universidade Estadual Paulista "Júlio de Mesquita Filho”, Franca, 2011.

GALVÃO, Olímpio José de Arroxelas. A economia de Pernambuco: da longa estagnação a um novo ciclo de crescimento sustentado. Rev. Econ. NE. Fortaleza, v. 46, n. 3, jul./set., 2015, p. 131-154.

GALVÃO, Sebastião de Vasconcellos. Município do Recife. Rev. Insti. Arq. Hist. Geog. Pern. Recife, n. 52, 1899, p. 233-338.

GOLDSMITH, Raymond W. Brasil 1850-1984: desenvolvimento financeiro sob um século de inflação. São Paulo: Haper \& Row, 1986. 557p.

HADDAD, C. L. S. Crescimento do produto real no Brasil. Rio de Janeiro: Ed. da FGV, 1978. 182p.

JUCÁ, Joselice V. Uma companhia urbana de Pernambuco no século XIX: a do Beberibe. Ciência \& Trópicos. Recife, 3(1), jan./jun., 1975, p. 25-39.

LEANDRO, Leonardo Milanez de Lima; MARCONDES, Renato Leite; SILVA, Fábio Carlos da. Crédito hipotecário na expansão e auge da economia da borracha: características da praça de Belém do Pará (1870-1899). História Econômica \& História de Empresas, v. 18, n. 1, 2015, p p. 153-189.

LEANDRO, Leonardo Milanez de Lima. Crédito hipotecário no Brasil: uma análise comparativa entre as praças de Belém e São Paulo (1870-1930). Tese (Doutorado em Desenvolvimento Sustentável do Trópico Úmido) - Núcleo de Altos Estudos Amazônicos, Universidade Federal do Pará, Belém, 2015.

LEVINE, Robert M. A velha usina - Pernambuco na federação brasileira 1889-1937. Rio de Janeiro: Paz e Terra, 1980. 299p.

MARCONDES, Renato Leite; HANLEY, Anne G. Bancos na transição republicana em São Paulo: o financiamento hipotecário (1888-1901). Estudos Econômicos. São Paulo, v. 40, n. 1, jan./mar. 2010, p. 103-131. DOI: http://dx.doi.org/10.1590/S0101-41612010000100004

MARCONDES, Renato Leite. O financiamento hipotecário da cafeicultura no vale do Paraíba paulista (1865-87). Revista Brasileira de Economia (Impresso), Rio de Janeiro, v. 56, n. 1, 2002, p. 147-170. DOI: http://dx.doi.org/10.1590/S0034-71402002000100006

Crédito privado antes da grande depressão do século XX: o mercado hipotecário.

Estudos Econômicos. São Paulo, v. 44, n. 4, out./dez. 2014, p. 749-786. DOI: http://dx.doi.org/10.1590/S0101-41612014000400004 
MELLO, Othon L. Bezerra de. A evolução da industria de tecidos de algodão em Pernambuco. Rev. Insti. Arq. Hist. Geog. Pern. v. 29, n. 135-142, jan. 1928/dez. 1929, 1930, p. 51-58.

MELO, Mario Lacerda. A cidade do Recife. Arquivos. Recife. 1(1), jan./jun., 1976, p. 165186.

METTENHEIM, Kurt E. Monetary Statecraft in Brazil: 1808-2014. New York: Routledge, 2016. 216p.

PIRES, Anderson. Café, finanças e bancos: uma análise do sistema financeiro da zona da mata de Minas Gerais (1889/1930). Tese (Doutorado em História Econômica) - Faculdade de Filosofia, Letras e Ciências Humanas, Universidade de São Paulo: Juiz de Fora, 2006.

SINGER, Paul Israel. Desenvolvimento econômico e evolução urbana: análise da evolução econômica de São Paulo, Blumenau, Porto Alegre, Belo Horizonte e Recife. São Paulo: Editora Nacional, 1977. 377p.

SUZIGAN, Wilson. Indústria brasileira - origem e desenvolvimento. São Paulo: Brasiliense, 1986. 403p.

SWEIGART, Joseph Earl. Financing and marketing Brazilian export agriculture: the coffee factors of Rio de Janeiro, 1850-1888. PhD Thesis - University of Texas, 1980. 674p.

VERGOLINO, José Raimundo de O. A economia de Pernambuco no período 1850-1900: uma interpretação. Série História do Nordeste (Recife). v. 1, n. 14, 1993. p. 99-117. 